SJ Quinney College of Law, University of Utah Utah Law Digital Commons

2019

Incorporation Without Assimilation: Legislating Tribal Civil Jurisdiction Over Non-Members

Alexander Tallchief Skibine

Follow this and additional works at: https://dc.law.utah.edu/scholarship

Part of the Indian and Aboriginal Law Commons 


\title{
INCORPORATION WITHOUT ASSIMILATION: LEGISLATING TRIBAL CIVIL JURISDICTION OVER NON-MEMBERS
}

\author{
Alex Tallchief Skibine* \\ INTRODUCTION
}

The United States began signing treaties with Indian Nations in $1778,{ }^{1}$ and in 1831 the U.S. Supreme Court described the Indian nations existing within the territorial boundaries of the United States as Domestic Dependent Nations. ${ }^{2}$ Until 1978, Indian nations were thought to possess all the inherent sovereign powers over their territories that had not been taken away by Congress or given up in treaties. $^{3}$ However, preoccupied by the assertion of tribal jurisdiction over individuals who were not tribal members, the Supreme Court in 1978 devised what became known as the implicit divesture doctrine. ${ }^{4}$ Under that doctrine, Indian tribes are said to have lost all inherent sovereign powers inconsistent with their status as domestic Dependent Nations. ${ }^{5}$ As a result of this doctrine, since 1978, the tribes initially lost all inherent criminal jurisdiction over non-tribal members, ${ }^{6}$ and as will be explained below, a good deal of civil or regulatory jurisdiction as well. ${ }^{7}$

The Court's jurisprudence in this area has been almost universally condemned by leading scholars as being confusing to the point of incoherence. ${ }^{8}$ These

${ }^{*}$ S.J. Quinney Professor of Law, University of Utah S.J. Quinney College of Law. J.D. Northwestern University Pritzker School of Law. Prior to joining Academia, the author served as Deputy Counsel for Indian Affairs for the Committee of the U.S. House of Representatives having jurisdiction over most legislation related to Indian Affairs. The proposal presented here draws from that experience. This research was made possible, in part, through a grant from the Albert and Elaine Borchard Fund for Faculty Excellence.

${ }^{1}$ Treaty with the Delaware Nation, 7 Stat. 13 (1778). In doing so, the United States followed a tradition started by the Europeans Nations.

${ }^{2}$ Cherokee Nation v. Georgia, 30 U.S. 1 (1831).

${ }^{3}$ See Felix Cohen's HANDBOOK OF FEDERAL INDIAN LAW (2012 Ed.) at 222223.

${ }^{4}$ Oliphant v. Suquamish Indian Tribe, 435 U.S. 191 (1978)(Holding Indian tribes implicitly divested of criminal jurisdiction over non-Indians.)

${ }_{6}^{5}$ Id., at 208.

${ }^{6}$ Parts of the Supreme Court decisions in the criminal area were overturned legislatively. See notes....infra.

7 This paper will use the term "non-members" to describe those individuals who are not members of the tribe asserting jurisdiction in a given case.

${ }^{8}$ See for instance, Philip P. Frickey, A Common Law for Our Age of Colonialism, : The Judicial Divestiture of Indian Tribal Authority over nonmembers, 109 Yale L.J. 1 (1999), David H. Getches, Conquering the Cultural Frontier: The New Subjectivism of the Supreme Court in Federal Indian Law, 84 Calif. L. Rev. 1573 (1996), Matthew L.M. Fletcher, The Supreme Court and Indian Policy, 85 Neb. L. Rev. 121 (2006), Michalyn Steele, Plenary Power, Political Questions, and Sovereignty in Indian Affairs, 63 U.C.L.A. L. Rev. 666 (2016). 
scholars have argued that when it comes to gauging tribal civil jurisdiction over non-members, the Implicit Divestiture doctrine is a moribund doctrine of federal common law unmoored from any congressional policies or constitutional values. It is a doctrine that has been manipulated by the Court to achieve politically desired results. Others have been more circumspect in criticizing or condemning the doctrine. ${ }^{9}$ Whether justifiable or not, the various formulations of the doctrine has resulted in confusion and dis-uniformity in the lower courts when it comes to determine the extent of tribal jurisdiction over non-members. ${ }^{10}$

While some scholars have offered constructive suggestions and insightful alternatives to the doctrine, ${ }^{11}$ in the wake of the recent 4-4 vote in Dollar General v. Mississippi Band of Choctaw, ${ }^{12}$ one has to wonder if the Court is at all willing to reconsider its approach. While I have in the past joined the ranks of those advocating for the Court to adopt a different approach, ${ }^{13}$ in this Article I suggest that the time is ripe to consider legislative solutions to remedy the current state of uncertainty when it comes to the extent of tribal civil jurisdiction over nonmembers. ${ }^{14}$ After all, Congress is the entity named in the Constitution to regulate commerce with Indian tribes. ${ }^{15}$ As early as 1855, the Court confirmed that although Indian Nations had retained much of their inherent sovereignty over both their people and territories, the U.S. Congress possessed "plenary authority" to

\footnotetext{
${ }^{9}$ See for instance, Michael Doran, Redefining Sovereignty for the Era of Fundamental Rights (forthcoming, Indiana Law Review), Electronic Copy available at: https://ssrn.com/abstract=3398215. (Arguing that the Court devised the doctrine as a way to recognize the continued existence of tribal sovereignty while at the same time protecting the fundamental rights of people who are not members of the tribe.) See discussion infra at notes...

${ }^{10}$ See Alex Tallchief Skibine, Formalism and Judicial Supremacy in Federal Indian Law, 32 Am. Ind. L. Rev. 391, 409-414 (1007-08).

${ }^{11}$ See Matthew Fletcher, A Unifying Theory of Tribal Sovereignty, 46 Ariz St. L. J. 779 (2014)(Hereinafter Fletcher, Unifying Theory), Katherine Florey, Beyond Uniqueness, Reimagining Tribal Courts' Jurisdiction, 101 Cal. L. Rev. 1499 (2013) (hereinafter, Florey Beyond Uniqueness).

${ }^{12} 136$ S. Ct. 2159 (2016). The tie meant that the decision below in favor of tribal court jurisdiction stood.

${ }^{13}$ See Alex Tallchief Skibine, Constitutionalism, Federal Common Law, and the Inherent Powers of Indian Tribes, 39 Am. Ind. L. Rev. 77 (2014-15).

${ }^{14}$ Others have also argued for legislative solutions. See for instance, Ann E. Tweedy, Connecting the Dots Between the Constitution, the Marshall Trilogy, and United States $v$. Lara: Notes Toward a Blueprint for the Next Legislative Restoration of Tribal Sovereignty, 42 U. Mich. J. L. Reform 651 (2009)(hereinafter Tweedy, Connecting the Dots). See also R. Stephen McNeill, Note, In a Class by Themselves: A Proposal to Incorporate Tribal Courts into the Federal Court System Without Compromising Their Unique Status as “Domestic Dependent Nations," 65 Wash. \& Lee L. Rev. 283 (2008)(advocating for a restoration of tribal court civil jurisdiction but recommending the creation of a new Federal Circuit Court of Appeals to review tribal court decisions for violation of constitutional rights.)

${ }^{15}$ U.S. Constitution, art. I, Section 8, cl. 3.
} 
govern those domestic nations. ${ }^{16}$ While I am aware that the tribes would face an uphill battle in attempting to enact such legislation, it is not an impossible task. Scholars have already noted that Tribes are surprisingly adept at successfully pushing legislation through Congress. ${ }^{17}$ As I and others have suggested, however, it might be easier for such legislation to be enacted on a tribe by tribe basis. ${ }^{18}$

This Article, therefore, discusses the various options available to fashion a legislative correction to the Supreme Court jurisprudence in the area of tribal civil jurisdiction over non-members. PART I summarizes the Court's jurisprudence in the area of tribal civil jurisdiction over non-members and outlines the major problems the Court has noted in recognizing such tribal jurisdiction. PART II outlines three potential legislative proposals that would confirm tribal civil jurisdiction over non-members while also attempting to meet the concerns outlined by the Court. Because the three proposals all involve granting all or at least some of the protections of the Bill of Rights to non-members subject to tribal jurisdiction, this Part also discusses the concerns with incorporating Indian tribes within our constitutional system. Taking such concerns seriously, PART III comes up with a new legislative proposal which would minimize federal court interference with the legal and cultural distinctiveness of the tribal judiciaries.

Simply put, the proposal is to reconfirm the civil jurisdiction of any tribal court over non-member defendants in all causes of action arising on the reservation as long as the tribal court has met the requirements for establishing personal jurisdiction over the parties as that term is defined and understood under applicable U.S. Supreme Court precedents. In addition, tribal courts determinations concerning the existence of personal jurisdiction would be appealable to federal courts. Furthermore, in order to facilitate passage of this legislative proposal, I am recommending allowing non-members the option of removing to federal court cases filed against them in tribal courts if certain conditions are met.

PART I: TRIBAL CIVIL JURISDICTION OVER NON-MEMBERS

\section{The Court's Jurisprudence}

${ }^{16}$ United States v. Rogers, 45 U.S. 567, $571-74$ (1846). See Maggie Blackhawk, Federal Indian Law as Paradigm within Public Law, 132 Harv. L. Rev. 1789, at 1829-30 (2019). On congressional authority over Indian tribes, see Gregory Ablavsky, Beyond the Indian Commerce Clause, 124 Yale L.J. 1012 (2015).

${ }^{17}$ See for instance, Kirsten Matoy Carlson, Congress and Indians, 86 U. Colo. L. Rev. 77 (2015). See also Carlson, Legislating Against the Odds, 56 Harv. J. on Legis 23 (2019).

8 See Tweedy, Connecting the Dots, supra at note 14, at pp 702-709 (2009)(suggesting a piecemeal or subject specific approach.) See also Alexander Tallchief Skibine, The Supreme Court's Last 30 years of Federal Indian Law: Looking for Equilibrium or Supremacy? 8 Colum. J. of Race and Law 277, at 318-320 (2018). 
Because scholars and commentators have already spent considerable amount to ink analyzing the Court's jurisprudence in this area, ${ }^{19}$ I will only go over the highlights in this analysis. My purpose here is to show that, as in other areas of federal Indian law, while the implicit divestiture doctrine may have started as a sensible limiting principle on tribal sovereignty, it ended up being used as a political tool to privilege the rights and interests of non-Indians and non-tribal members at the expense of tribal sovereign interests in governing their territories. ${ }^{20}$

The implicit divestiture doctrine has its roots with the 1978 decision in Oliphant v. Suquamish Indian Tribe, ${ }^{21}$ where the Supreme Court ruled that Indian tribes had been implicitly divested of the inherent sovereign power to prosecute non-Indians. According to the Court, such inherent power had been divested because its exercise by the tribes was "inconsistent" with the tribes' status as Domestic Dependent Nations existing within the borders of the United States. ${ }^{22}$ The Court further held that it was inconsistent with tribal status for tribes to exercise any inherent power in conflict with the overriding sovereign interests of the United States. ${ }^{23}$ In Oliphant such conflict existed because these non-Indians could be prosecuted by the tribes without being given all the protections of the Constitution's Bill of Rights. ${ }^{24}$ This was a consequence of Talton v. Mayes, ${ }^{25}$ where the Court held that Indian tribes did not derive their governmental powers from the Constitution and therefore were not bound by it.

Although Oliphant only dealt with the tribal power to criminally prosecute non-Indians, the case was extended a few years later to tribal regulatory power over non-members. The issue in Montana v. United States ${ }^{26}$ was whether the Crow Indian Tribe could regulate non-members fishing on state owned lands within the exterior boundaries of the Crow Indian reservation. After noting that the restriction on tribal criminal jurisdiction recognized in Oliphant also supported the proposition that "the exercise of tribal power beyond what is necessary to protect tribal self-government or to control internal relations is inconsistent with the dependent status of tribes," 27 the Montana court came up with the "general proposition that the inherent powers of an Indian tribe do not extend to the

${ }^{19}$ See sources listed at note 8 . See also, Tweedy, Connecting the Dots, supra at note 14. for a comprehensive treatment of tribal civil jurisdiction over non-members see Sarah Krakoff, Tribal Civil Jurisdiction over Nonmembers: A Practical Guide of Judges, 81 U. Colo. L., Rev. 1187 (2010).

20 See Alex Tallchief Skibine, From Foundational Law to Limiting Principles in Federal Indian Law, 80 Mont. L. Rev. 67 (2019).

${ }^{21} 435$ U.S. 191 (1978).

${ }^{22}$ Id., at 208.

${ }^{23}$ Id., at 209.

${ }^{24}$ Id., at 210.

25163 U.S. 376 (1896).

${ }^{26} 450$ U.S. 544 (1981).

${ }^{27} 450$ U.S. at 564. 
activities of nonmembers of the tribe." ${ }^{28}$ The Court quickly added, however, that in certain circumstances

Indian tribes retain inherent sovereign power to exercise some forms of civil jurisdiction over non-Indians on their reservations, even on nonIndian fee lands. A tribe may regulate, through taxation, licensing, or other means, the activities of nonmembers who enter consensual relationships with the tribe or its members, through commercial dealing, contracts, leases, or other arrangements. A tribe may also retain inherent power to exercise civil authority over the conduct of non-Indians on fee lands within its reservation when that conduct threatens or has some direct effect on the political integrity, the economic security, or the health or welfare of the tribe. ${ }^{29}$

These two exceptions to Montana's general proposition or rule would come to be known as the consensual relations exception and the self-government exception. Although not explicitly spelled out by the Court, it can be inferred that the two exceptions reflect what the Montana Court believed were powers "necessary to protect tribal self-government or to control internal relations. ${ }^{30}$ In the wake of Montana, some tribal advocates expressed the feeling that they could work with these principles, no doubt envisioning a broad scope for the two exceptions. Initially, the Court seemed to go along. Thus, in National Farmers Union v. Crow Tribe ${ }^{31}$ the Court insisted that before filing their challenge to tribal jurisdiction in federal court, non-member plaintiffs had to exhaust their tribal court remedies because "the existence and extent of a tribal court's jurisdiction will require a careful examination of tribal sovereignty, and the extent to which that sovereignty had been altered, divested, or diminished." 32 Two years later, in another tribal exhaustion of remedies case, the Court stated "Because the Tribe retains all inherent attributes of sovereignty that have not been divested by the Federal Government, the proper inference from silence... is that the sovereign power... remains intact." 33 As further explained below, the honeymoon between the tribes and the implicit divestiture doctrine did not last long.

Since Montana, when it comes to regulatory jurisdiction, except for an early victory in Merrion v. Jicarilla Apache upholding tribal taxation of a non-Indian energy corporation leasing lands from the tribe, ${ }^{34}$ and a mixed result in Brendale $v$.

${ }^{28}$ Id., at 565.

${ }^{29}$ Id.

${ }^{30}$ See note 27 supra.

31471 U.S. 845 (1985).

${ }^{32}$ Id., at $855-56$.

33480 U.S. 9,18 (1987).

34455 U.S. 130 (1982). At the time, Montana was held to only apply to non-member fee land within the reservation. Whether the same result would obtain after Nevada v. Hicks, 533 U.S. 353 (2001), is debatable. See discussion infra at notes ... 
Confederated Tribes (zoning), ${ }^{35}$ the tribal interests lost the only other case, Atkinson Trading $v$. Shirley, ${ }^{36}$ involving taxation of a non-Indian hotel owner located on non-Indian fee land within the Navajo reservation. ${ }^{37}$ When it comes to the adjudicative jurisdiction of the tribal courts, the tribal interests lost all three cases, ${ }^{38}$ before deadlocking 4-4 without an opinion in Dollar General. ${ }^{39}$

For a while, some tribal advocates had hoped that the Montana analysis would only be applicable to tribal regulatory authority and not to the adjudicatory jurisdiction of tribal courts. The Court itself gave some reasons for tribal optimism. For instance, in Iowa Mutual v. LaPlante, ${ }^{40}$ it stated "Tribal authority over the activities of non-Indians on reservation lands is an important part of tribal sovereignty. Civil jurisdiction over such activities presumptively lies in the tribal courts." ${ }^{41}$ However, the Court dispelled that notion in 1997 with Strate v. A-1 Contractors, ${ }^{42}$ when it held that Montana was applicable to limit both tribal regulatory and adjudicative jurisdiction and that "A tribe adjudicative Jurisdiction does not exceed its legislative jurisdiction." 43

The issue in Strate was whether the tribal court had jurisdiction to hear a lawsuit filed by one nonmember against another nonmember over a run of the mill traffic accident that took place on a state highway running through the reservation. The Court held that opening the tribal court to such suits was "not necessary to tribal self-government and ... is not crucial to the political integrity, the economic security, or the health and welfare of the [Three Affiliated Tribes " $^{, 4}$ The importance of Strate is not only that it substantially narrowed Montana's second exception but also that it laid down the rule that a tribal court has jurisdiction over

${ }^{35} 492$ U.S. 408 (1990). The case is a good example about how politically manipulated the implicit divestiture doctrine can be. In Brendale, four justices held that the Tribes can never zone the fee lands of non-members, three Justices held that tribes could always do so. The other two Justices, Stevens and O'Connor, decided to split the baby in two and allowed the tribe to zone non-member fee land in one part of the reservation (closed part) but not the other (open part). Although these two Justices made a valiant attempt to justify their result, they were severely criticized by the other seven Justices.

${ }^{36} 532$ U.S. 645 (2001).

${ }^{37}$ Although some may categorize South Dakota v. Bourland, 508 U.S. 679 (1993) as involving the implicit divestiture doctrine, this is not the case as the Court ended up remanding on that issue. It was plain, however, that the author of the Opinion, Justice Thomas, had no doubt the tribe would lose since he stated "After Montana... tribal sovereignty over nonmembers cannot survive without express congressional delegation ... and is therefore not inherent." Id., at 695, n.15 (1903).

${ }^{38}$ Strate v. A-1 Contractors, 520 U.S. 438 (1997), Nevada v. Hicks, 533 U.S. 353

(2001), Plains Commerce Bank v. Long Family Land \& Cattle, 554 U.S. 316 (2008).

39 Dollar General v. Mississippi Band of Choctaw, 136 S. Ct. 2159 (2016).

40480 U.S. 9 (1987).

${ }^{41} \mathrm{Id}$., at 18 .

42520 U.S. 438 (1997).

${ }^{43}$ Id., at 453.

${ }^{44}$ Id., at 459. 
non-members only in cases where the tribal legislative body could also have regulated the activities of such non-members. ${ }^{45}$

In both Strate and a 2001 case, Atkinson Trading v. Shirley, ${ }^{46}$ involving tribal taxing authority over non-members, the Court went out of its way to specify that the lands where the non-member activities took place was owned in fee by nonmembers. However, later in 2001, the Court in Nevada v. Hicks unanimously held that the Montana principle extended to both non-Indian and Indian owned land. ${ }^{47}$ The issue in Hicks was whether a tribal member could sue two state game wardens in tribal court. Hicks had alleged that the wardens had damaged his property and violated his civil rights when they searched his home which was located on Indian owned land within the Fallon Paiute-Shoshone Tribes reservation in western Nevada. The wardens had conducted the search as part of an investigation into alleged violations by Hicks of state hunting regulations committed outside the reservation.

Justice Scalia wrote the opinion for the Court and although he concluded that "tribal authority to regulate state officers, in executing process related to the violation, off reservation, of state laws is not essential to tribal self-government or internal relations," 48 his analysis deviated substantially from previous implicit divestiture cases. Thus, after stating that "state sovereignty does not end at a reservation's border," 49 he asserted that evaluating the tribal right of selfgovernment requires "an accommodation between the interests of the Tribes and the Federal Government, on the one hand, and those of the State, on the other." ${ }^{50}$ In other words, he performed some sort of "balancing of the interests test." Although all Justices agreed to extend Montana to activities conducted on Indianowned land, the Court was badly split on what weight the status of the land should carry in performing any balancing of the interest test to determine whether the Tribe had jurisdiction.

Justice Scalia writing for the Court took the position that the status of the land can be, at times, an important factor. ${ }^{52}$ It should be noted, however, that only Justices Rehnquist and Ginsburg agreed with him on that specific point. Justices Souter, Kennedy and Thomas took the position that the status of the land was never a "primary jurisdictional fact." ${ }^{, 53}$ Finally, Justices O'Connor, Breyer, and Stevens thought that the status of the land was always an important consideration. ${ }^{54}$

${ }^{45}$ Id., at 453.

46532 U.S. 645 (2001)(Holding that the tribe could not impose a room occupancy tax on a hotel located inside the Navajo reservation but on non-Indian fee land.).

47533 U.S. 353 (2001)

${ }^{48}$ Id., at 364 .

${ }^{49}$ Id., at 361 .

${ }^{50}$ Id., at 362

${ }^{51}$ For a more retailed analysis, see Alex Tallchief Skibine, Making Sense Out of Nevada v. Hicks: A Reinterpretation, 13 St. Thomas L. Rev. 347 (2001).

${ }^{52}$ Id., at 370-374.

${ }^{53}$ Id., at 375-376 (Souter, concurring).

${ }^{54}$ Id., at 395-396 (O’Connor, concurring in part). 
Hicks created much confusion and disagreements concerning how expansive or narrow the holding was. ${ }^{55}$ Some courts have interpreted Hicks narrowly, ${ }^{56}$ others have disagreed. ${ }^{57}$ More recently, the $9^{\text {th }}$ Circuit held that Hicks was not applicable when there were no state law enforcement interests at stake. ${ }^{58}$ The $9^{\text {th }}$ Circuit also has taken the position that Hicks, or Montana for that matter, are not applicable to cases occurring on Indian owned land where the Tribe has retained a treaty right to exclude. $^{59}$

The last Supreme Court's opinion involving the implicit divestiture doctrine, Plains Commerce Bank v. Long Family Ranch, ${ }^{60}$ shows that the doctrine is so malleable that it can be easily manipulated to reach just about any kind of result. At issue was whether the tribal court had jurisdiction to hear a lawsuit brought by tribal members against a non-Indian bank alleging that the bank had discriminated against them by offering to sell land within the reservation to non-members on more favorable terms that it was willing to offer them. Although the land at issue was now owned by the non-Indian bank, the case clearly involved contractual or consensual relations as the land had been previously owned by the tribal plaintiffs who had forfeited the land to the bank but were attempting to repurchase it from that same bank. ${ }^{61}$ The Court in a 5-4 opinion per Justice Roberts held that the tribal court did not have jurisdiction because "the Tribe lacks civil authority to regulate the Bank's sale of its fee land." ${ }^{2}$ Thus, Justice Roberts took the position that Montana only allowed tribes to regulate the "conduct" of non-members in certain circumstances, ${ }^{63}$ but that the sale of land was not "conduct" for the purpose of allowing tribal jurisdiction under Montana. ${ }^{64}$

According to the tribal plaintiffs, however, the conduct at issue was not so much the "sale" of non-Indian land as it was the discrimination involved in the sale of land. ${ }^{65}$ Pushed to its ultimate limit, this decision would foreclose Indian

${ }^{55}$ For a recent summary of the various positions in a case where a cert petition is currently pending at the Supreme Court see Knighton v. Cedarville Rancheria, 922 F.3d 892, 899-902 (9 ${ }^{\text {th }}$ Cir. 2019).

56 See McDonald v. Means, 309 F.3d 530 (9 $9^{\text {th }}$ Cir. 2002), Smith v. Salish and Kootenai College, 434 F.3d 1127 ( $9^{\text {th }}$ Cir. 2006).

${ }^{57}$ MacArthur v. San Juan County, 497 F.3d 1057 (10 ${ }^{\text {th }}$ Cir. 2007).

${ }^{58}$ Window Rock Unified School District v. Reeves, 861 F.3d 894, 906 (9 ${ }^{\text {th }}$ Cir 2017).

59 See Water Wheel Camp Recreational Are v. La Rance, 642 F.3d 802 (9 ${ }^{\text {th }}$ Cir. 2011). For an insightful and comprehensive analysis of this issue, see Judith V. Royster, Revisiting Montana: Indian Treaty Rights and Tribal Authority over Nonmembers on Trust Lands, 57 Ariz. L. rev. 889 (2015).

${ }^{60} 554$ U.S. 316 (2008).

${ }^{61}$ The tribal plaintiffs had forfeited the land because they were unable to make the monthly mortgage payments.

${ }^{62} 554$ U.S. at 330.

${ }^{63}$ Id., at 332

${ }^{64}$ Id., at 334, (stating that "the distinction between sale of the land and conduct on it is well established... and entirely logical given the ...liberty interest of nonmembers.")

65 This why Justice Ginsburg, concurring in part and dissenting in part, argued that the Court should have just limited the tribal court remedy (forcing the sale of land to the 
tribes from ever sanctioning non-members for discriminating against tribal members when selling anything on the reservation. ${ }^{66}$

2. United States v. Lara and the Constitutionality of Legislation Reaffirming Tribal Inherent Civil Jurisdiction over Non-members

Before proceeding to describe potential legislative solutions to the Court's implicit divestiture doctrine, a word on the constitutionality of such legislation is in order. In United States v. Lara, ${ }^{67}$ the Court held that Congress could reaffirm the inherent power of Indian tribes to prosecute non-member Indians even though the Supreme Court in Duro v. Reina, ${ }^{68}$ had held that power to have been implicitly divested. ${ }^{69}$ At issue in Lara was the constitutionality of the so called Duro Fix legislation. ${ }^{70}$ That legislation had amended the Indian Civil Rights Act of 1968 to provide that the tribes' power of self-government included "the inherent power of an Indian tribe, hereby recognized and affirmed, to exercise criminal jurisdiction over all Indians." ${ }^{, 11}$ The question in Lara was whether the United States could prosecute Billy Jo Lara, an enrolled member of the Turtle Mountain Band of Chippewa, after the Spirit Lake Indian tribe had already prosecuted him for the same crime. Lara argued that because Congress could not have reaffirmed the inherent power of the tribe to prosecute him, the first (tribal) prosecution must have been done pursuant to a "delegation" of federal authority to the tribe. The second (federal) prosecution for the same crime, therefore, was barred by the Double Jeopardy clause of the United States Constitution. ${ }^{72}$

The Court held that Congress could indeed reaffirm the inherent power of Indian tribes to prosecute non-member Indians such as Lara, even after Duro v. Reina. In order to arrive at this conclusion, the Court found that decisions such as Oliphant and Duro were not constitutional decisions. Instead they were decisions based on Federal common law. The Duro-Fix legislation just "relaxes the

tribal Plaintiffs) while still upholding the tribal court jurisdiction over the discrimination claim. Id at 342-352.

${ }^{66}$ At least if such sales occurred on non-Indian fee land although some would argue that Hicks may have blurred any distinction between Indian and non-Indian owned land within a reservation.

${ }^{67} 541$ U.S. 193 (2004).

${ }^{68} 495$ U.S. 676 (1990).

${ }^{69}$ Duro had basically extended the rational of Oliphant which had dealt with tribal jurisdiction over non-Indians to tribal jurisdiction over non-member Indians, meaning members of other tribes than the prosecuting tribe.

${ }^{70}$ For a more comprehensive treatment, see Alex Tallchief Skibine, Duro v. Reina and the Legislation that Overturned It: A Power Play of Constitutional Dimensions, 66 S. Cal. L. Rev. 767 (1993).

${ }^{71} 25$ U.S. C. 1301(2).

${ }^{72}$ The Fifth Amendment to the U.S. Constitution reads in part "nor shall any person be subject for the same offence to be twice put in jeopardy of life or limb." 
restrictions... that the political branches had imposed on the tribes' exercise of inherent prosecutorial power." ${ }^{, 73}$ The Court further found that Oliphant and Duro

reflect the Court's view of the tribes' retained sovereign status as of the time the Court made them. They did not set forth constitutional limits that prohibit Congress from changing the relevant legal circumstances, i.e., from taking actions that modify or adjust the tribes' status. To the contrary, Oliphant and Duro make clear that the Constitution does not dictate the metes and bounds of tribal autonomy, nor do they suggest that the Court should second-guess the political branches' own determinations. $^{74}$

As I have argued elsewhere, however, Justice Breyer's opinion in Lara seems to be at odd not only with the actual rational of Duro, ${ }^{75}$ but also with the Montana line of cases. ${ }^{76}$ Thus, the Lara Court failed to mention that Montana had given a somewhat different explanation than Oliphant for divesting tribes of jurisdiction. ${ }^{77}$ Furthermore, unlike Oliphant and arguably Duro, the Montana Court never relied on or cited any congressional statutes reflecting a congressional support, explicitly or implicitly, for the proposition that tribal civil jurisdiction over non-members had been implicitly divested. ${ }^{78}$ Could this mean that the Lara analysis concerning the existence of congressional power to reaffirm the inherent powers of Indian tribes to criminally prosecute non-members would not be applicable to legislation reaffirming the existence of tribal inherent civil jurisdiction over non-members? Not really. For one, Justice Stewart in Montana relied completely on Oliphant when he wrote "Though Oliphant only determined inherent tribal authority in criminal matters, the principles on which it relied support the general proposition that the inherent powers of an Indian tribe does not extend to the activities of nonmembers of the tribe." 79

It has to be noted that although Billy Jo Lara had argued that his prosecution was conducted in violation of the Due Process Clause of the U.S. Constitution, the Court held that because of the procedural posture of the case "We need not, and we shall not, consider the merits of Lara's due process claim." ${ }^{\prime \prime 0}$ While the Court has never definitely addressed the validity of such due process claims and scholars have disagreed as to their merits, ${ }^{81}$ the more credible attacks on such legislation is

${ }^{73} 541$ U.S. at 200.

${ }^{74}$ Id., at 205.

${ }^{75}$ See Alex Tallchief Skibine, United States v. Lara, Indian Tribes, and the Dialectic of Incorporation, 40 Tulsa L. Rev. 47, 53-56.

${ }^{76}$ Id., at 56-57.

${ }_{78}^{77}$ See discussion supra at.....

${ }^{78}$ Skibine, Dialectic of Incorporation, at 57.

${ }^{79}$ Montana v. United States, 450 U.S. 544, 565 (1981).

${ }^{80}$ Id., at 209.

${ }^{81}$ Compare Gould, "Tough Love for Tribes: Rethinking Sovereignty after Atkinson and Hicks, 37 New Eng. L. Rev. 669 (2003)(against the Duro Fix) with Samuel E. Ennis, 
the potential lack of available due process during criminal prosecutions. ${ }^{82}$ Even if they have some validity, which is by no means certain, ${ }^{83}$ such due process arguments would have much less force when considering legislation confirming tribal civil adjudicative jurisdiction over non-members. In such civil cases, controversial tribal provisions such as the lack of any obligations to provide counsels to indigent defendants in tribal criminal cases would not be implicated.

Finally, even though he is no longer on the Court, Justice Kennedy's concerns as reflected by his Duro opinion and his Lara concurrence about Congress subjecting to tribal jurisdiction non-tribal members who have not consented to such jurisdiction should not be forgotten. In Duro, ${ }^{84}$ after holding that Indian tribes had no criminal jurisdiction over non-member Indians, Justice Kennedy concluded by stating "The retained sovereignty of the tribe is but a recognition of certain additional authority the tribes maintain over Indians who consent to be tribal members." " Justice Kennedy picked up on his "consent of the governed" theory in his Lara concurrence, ${ }^{86}$ where he stated

The Constitution is based on a theory of original, and continuing, consent of the governed. Their consent depends on the understanding that the Constitution has established the federal structure, which grants the citizen the protection of two governments, the Nation and the State... Here, contrary to this design, the National Government seeks to subject a citizen to the criminal jurisdiction of a third entity to be tried for conduct occurring wholly within the territorial borders of the Nation and one of the States. This is unprecedented. There is a historical exception for Indian tribes, but only to the limited extent that a member of a tribe consents to be subjected to the jurisdiction of his own tribe. ${ }^{87}$

It is unclear whether Justice Kennedy was attempting to make a constitutional argument. Perhaps it can best be described as a quasi-constitutional one. The noted

Reaffirming Indian Tribal Court Criminal Jurisdiction over Non-Indians: An Argument for a Statutory Abrogation of Oliphant, 57 UCLA L. Rev. 553 (2009)(In favor).

${ }^{82}$ For an analysis of the arguments involved see Comment, Will Trachman, Tribal Criminal Jurisdiction after U.S. v. Lara: Answering Constitutional Challenges to the Duro Fix, 93 Cal. L. Rev. 849 (2005).

${ }^{83}$ See for instance Morris v. Tanner, 288 F.Supp.2d 1133, 143 ((2003)(finding no due process violation because accused could invoke violation of the Indian Civil Rights Act which made provisions similar to the Bill of Rights applicable to the tribal court), and Means v. Navajo Nation, 432 F.3d 924. 935 ( $9^{\text {th }}$ Cir. 2005)(Finding no violation of Due Process because of the applicability of the Indian Civil Rights Act and the fact that under Navajo Nation law, the right to appointed counsel was provided to anyone under the jurisdiction of the Navajo Nation.)

${ }^{84}$ Duro v. Reina, 495 U.S. 676 (1990).

${ }^{85}$ Id., at 693.

${ }^{86} 541$ U.S. 193, 211-214 (Justice Kennedy concurring) (2004).

${ }^{87}$ Id., at 212. 
scholar Philip Frickey once described Kennedy's argument in Lara as mystical, stating “Justice Kennedy's opinion is mystical, in two senses of the word. His argument from deep constitutional structure and ongoing consent of the governed is not only obscure, but also seems to depend upon a direct communication with a sacred constitutional omnipresence to which at least some of the rest of us are not privy." ${ }^{\prime 88}$ Whatever one might think of the argument, one thing is clear, Kennedy in his Lara opinion was attempting to provide strong legal policy arguments for not extending tribal jurisdiction over non-consenting individuals who are not tribal members.

\section{The Court's Major Concerns with Tribal Civil Jurisdiction over Non-members}

In spite of the Court claiming to decide the existence of tribal civil jurisdiction on whether such jurisdiction is "necessary" to tribal self-government or whether there are consensual relations of the qualifying kind, some of the Justices who routinely ruled against tribal jurisdiction have at times highlighted what was really troubling them with tribal civil jurisdiction over non-members. Professor Fletcher has already summarized what non-tribal institutions, such as the Supreme Court, see as the main objections to tribal civil jurisdiction over non-members. ${ }^{89}$ Although I endorse his analysis, here are some additional comments summarizing my views about these objections. The following six objections to tribal court jurisdiction are subjectively listed below in order of importance.

First is the fact that the United States Constitution does not apply to Indian tribes. Early on, the Court ruled in Talton v. Mayes that unlike the federal and state governments, tribal governments were not bound by the Constitution. ${ }^{90}$ As stated by the Court,

the existence of the right in congress to regulate the manner in which the local powers of the Cherokee Nation shall be exercised does not render such local powers federal powers arising from and created by the constitution of the United States. It follows that, as the powers of local self-government enjoyed by the Cherokee Nation existed prior to the constitution, they are not operated upon by the fifth amendment, which, as we have said, had for its sole object to control the powers conferred by the constitution on the national government. $^{91}$

Justice Kennedy was the most concerned among the Justices with that fact. His decision in Duro v. Reina, ${ }^{92}$ denying Indian tribes criminal jurisdiction over nonmember Indians is normatively based on the fact that as citizens of the United

${ }^{88}$ See Philip P. Frickey, (Native) American Exceptionalism in Federal Public Policy, 119 Harv. L. Rev. 431, 467 (2005).

${ }^{89}$ See Fletcher, Unifying Theory, supra note10, at pp. 822-828.

90163 U.S. 376 (1896). This is not to say that tribal courts do not believe in fundamental fairness and due process. See Matthew L.M. Fletcher, Indian Courts and Fundamental Fairness: Indian Courts and the Future Revisited, 84 U. Colo. 59 (2013).

91163 U.S. 376,384 (1896).

92495 U.S. 676, 696-694 (1990). 
States, non-member Indians have not consented to be governed by tribal entities outside the structure of the Constitution. ${ }^{93}$ Justice Kennedy restated these concerns in his concurring opinion in United States v. Lara, when he stated "Lara, after all, is a citizen of the United States. To hold that Congress can subject him, within our borders, to a sovereignty outside the basic structure of the Constitution is a serious step." 94

This argument, however, cannot be overstated. As explained below, the 1968 Indian Civil Rights Act made almost all the provisions of the United States Bill of Rights applicable to tribal governments and their courts. ${ }^{95}$ In addition, not being bound by the United States Constitution is what make tribal courts unique. As explained below, ${ }^{96}$ some believe that making the Constitution applicable to tribal courts would completely assimilate them into the United States constitutional system and would amount to a "Devils Bargain." 97

Second is the lack of independence in some tribal judiciaries. In other words, some tribes do not have the same principle of separation of power that we have. Therefore, some tribal judges do not have lifetime tenure and can be fired by the tribes' Executive or Legislative branches. Justice Kennedy once stated that tribal courts were often "subordinated to the political branches of the tribal governments." ${ }^{98}$ In a later case, Justice Souter agreed with this assessment. ${ }^{99}$ While this is true of some tribal governments, it seems that the great majority of tribal courts have in fact a significant amount of independence from the other branches of the tribal government. ${ }^{100}$ Besides, not all judges are as independent as federal judges. State judges, for instance, may be independent from the state executive and legislative branches, but they are not immune from political pressures as many of them are elected and some can even accept campaign contributions. ${ }^{101}$

Third is the fact that there is no mechanism for federal or state court to review tribal decisions even if the grounds for the tribal court's decision are based on federal or state law. As stated by Justice Souter, this would result in "a risk of

${ }^{93}$ See discussion supra at notes.......

94541 U.S. 193, 212 (2004)(Kennedy concurring).

${ }^{95}$ See discussion infra at notes......

96 Se discussion infra at notes......

97 Id., at notes......

98495 U.S. 676, at 693.

${ }^{99}$ Nevada v. Hicks, 533 U.S. at 385.

${ }^{100}$ See Kirke Kickingbird, Striving for the Independence of Native American Tribal Courts, 36 Hum. Rts. 16 (Winter 2009), Frank Pommersheim, Tribal Courts Jurisprudence: A Snapshot from the Field, 21 Vt. L. Rev. 7, 15. (1996).

${ }^{101}$ For a discussion on how problematic such contributions can be, see Caperton v. A.T. Massey Coal Co. 129 S. Ct 2252 (2009). For an overview of issues relating to Judicial bias, see Dmitry Bam, Recusal Failure, 18 NYU J. Leg. \& Pub. Pol. 631 (2015), Comment, Due Process and Judicial Disqualification: The need for Reform, 38 Pe. L. Rev. 1109 (2011). 
substantial disuniformity in the interpretation of state and federal law." ${ }^{102}$ While this observation is correct, ${ }^{103}$ the proposal I am putting forth in this article will go a substantial way in alleviating this concern. ${ }^{104}$

Fourth is the so-called Democratic Deficit: The fact that non-members cannot participate in the political life of the tribes in that they cannot vote in tribal elections. ${ }^{105}$ For instance, Justice Kennedy in Duro v. Reina stated that the Court should "hesitate to adopt a view of tribal sovereignty that would single out another group of citizens, non-member Indians, for trial by political bodies that do not include them." 106 Related to this concern is the accusation that tribal bodies that do not include non-members would be biased against such political outsiders. ${ }^{107}$ Professor Fletcher called this objection "racial exceptionalism." ${ }^{108}$ However, as he noted, citizens of one state are routinely subjected to the jurisdiction of courts located in other states. ${ }^{109}$ In addition, foreigners can also be sued in the domestic courts of the United States. It also has to be noted that in earlier decisions, the Court did not agree with these concerns. For instance in Iowa Mutual v.. Laplante, the Court stated:

Petitioner also contends that the policies underlying the grant of diversity jurisdiction - protection against local bias and incompetence-justify the exercise of federal jurisdiction in this case. We have rejected similar attacks on tribal court jurisdiction in the past... Moreover, the Indian Civil Rights Act provides non-Indians with various protections against unfair treatment in the tribal courts. ${ }^{110}$

Fifth, many non-tribal judges see tribal law as foreign and different than regular American law. They claim that tribal law is frequently unwritten, and based on

${ }^{102}$ Id., at 385.

103 Although the Court in National Farmers Union v. Crow Tribe, 471 U.S. 845 (1985), allowed non-members to challenge tribal court jurisdiction in Federal courts, in a subsequent case, Iowa Mutual v. LaPlante, 480 U.S. 9 (1987), it took the position that once a federal court determined that the tribal court did have jurisdiction "proper deference to the tribal court system precludes relitigation of issues raised by [the non-member] and resolved in tribal court." Id., at p. 19.

${ }^{104}$ Se discussion infra at notes...

105 That expression as applied to Indian tribes was first coined and noted by Professor T. Alexander Aleinikoff in his book, Semblance of Sovereignty: The Constitution, The States, and American Citizenship 115 (2012).

106495 U.S. 676, at 693.

107 Many of these accusations and concerns were rebutted by Professor Bethany Berger in Justice and the Outsider: Jurisdiction over Nonmembers in Tribal Legal Systems, 37 Ariz. St. L.J. 1047 (2005).

${ }^{108}$ Fletcher, A Unifying Theory, at 826-827.

${ }^{109}$ Id., at 824.

${ }^{110} 480$ U.S. 9, 18-19 (1987). 
orally transmitted customs and traditions. ${ }^{111}$ For instance, Justice Kennedy once expressed the view that tribal courts were "influenced by unique customs... unspoken practices, and norms." 112 Justice Souter described Tribal law as the results of a "complex mix... which would be unusually difficult for an outsider to sort out." ${ }^{\text {"13 }}$ At least one scholar has noted, however, that most cases involving non-members would be based on western European legal concepts and would not involve traditional tribal law. ${ }^{114}$

Sixth is not an objection as much as a pragmatic consideration based on political expediency. It is the fact that the Court is under the impression that in most of the cases where tribal jurisdiction has been denied, the tribal plaintiff could sue in state or federal court. For instance, in Nevada v. Hicks, Justice Scalia observed that the Tribe or its members could always "invoke the authority of the Federal Government and federal courts (or the state government and state courts) to vindicate constitutional or other federal and state- law rights." 115 Similarly in Strate v. A-1 Contractors, Justice Ginsburg concluded her opinion denying tribal court jurisdiction by stating "Gisela Fredericks may pursue her case against A-1 Contractors and Stockert in the state forum open to all who sustain injuries on North Dakota's Highway. Opening the Tribal Court for her optional use is not necessary to tribal self-government." 116

Although this perception has, legally speaking, some validity, ${ }^{117}$ it is problematic for many reservation Indians. While I do not doubt that tribal governments and Indian owned businesses would have no problem filing lawsuits in federal or state courts, the same cannot be said of the many reservation Indians who live below the poverty level. ${ }^{118}$ For such individuals, the same criticisms that is levelled when courts authorize non-Indians to be sued in culturally unfamiliar and different tribal courts can be applied to forcing poverty stricken reservation Indians to file lawsuits in federal or state courts.

${ }^{111}$ Professor Fletcher has referred to this objection as "cultural Exceptionalism." See A Unifying Theory, at 826.

${ }_{112}$ Duro v. Reina, 495 U.S. 676, at 693 (1990).

${ }^{113}$ Nevada v. Hicks, 533 U.S. 353, at 384-385 (2001)(Justice Souter, concurring).

${ }^{114}$ Matthew L.M. Fletcher, Towards a Theory of Intertribal and Intratribal Common Law, 43 Hous. L. Rev. 701 (2006).

115533 U.S. 353 at 373 (2001).

116520 U.S. 438,459 (1997).

${ }^{117}$ For instance, in Three Affiliated Tribes of the Ft. Berthold Reservation v. Wold Eng'g, 467 U.S. 138 (1984), the Court stated "As a general matter, tribal self-government is not impeded when a State allows an Indian to enter its courts on equal terms with other persons to seek relief against a non-Indian concerning a claim arising in Indian Country." Id., at 148-49.

${ }^{118}$ For a summary of current economic conditions on Indian reservations, see Robert J. Miller, Sovereign Resilience: Reviving Private-Sector Economic Institutions in Indian Country, 2018 B.Y.U. L. Rev. 1332, at 1335-1339 (2018). 


\section{PART II: Potential Legislative Solutions Tending to AlLEVIATE THE COURT'S CONCERNS}

Although there were previous legislative proposals introduced in Congress, for one reason or another, such proposals never made it into law. ${ }^{119}$ In all the solutions described below, the proposed statutes would first confirm or reaffirm the jurisdiction of tribal courts over many if not all lawsuits arising in Indian Country. ${ }^{120}$ However, because the principal concern of the Court seems to be the lack of constitutional protections afforded litigants in tribal courts, the following three proposals would afford non-member litigants either all or many of the protections guaranteed under the United States Constitution Bill of Rights. All three proposals would also provide some sort of federal court review of alleged violations of rights guaranteed by the legislation.

\section{The VAWA 2013 Model: Guaranteeing Non-members Many If Not All Constitutional Protections in Tribal Courts}

After some 35 years, tribal advocates finally succeeded in enacting legislation partially overturning the 1978 Court's decision in Oliphant v. Suquamish Indian Tribe that had divested tribes of criminal jurisdiction over non-Indians. ${ }^{121}$ Thus, what is now known as VAWA 2013 reaffirmed tribal jurisdiction over all people, Indians and non-Indians, accused of certain crimes of domestic violence provided certain conditions were met and some constitutional rights guaranteed to these defendants. ${ }^{122}$

Although previous legislation, known as the Duro Fix, ${ }^{123}$ overturning a Supreme Court decision denying tribal criminal jurisdiction over non-member Indians had simply reaffirmed the existence of such inherent tribal jurisdiction over such crimes, ${ }^{124}$ this partial Oliphant Fix ended up being more complicated. ${ }^{125}$ In order to get Congress's agreement to the legislation, tribal interests had to agree to the following:

${ }^{119}$ See Alex Tallchief Skibine, Last 30 Years of Federal Indian Law, supra note 17, at 318-320 (describing past legislative proposals.)

${ }^{120}$ Indian Country is a term of art derived from 18 USC 1151 according to which the following are treated as Indian lands for the purpose of jurisdictional analysis: 1. All lands within Indian reservations, 2. All trust lands held by the U.S. for the benefit of Indians or tribes, 3. Lands set aside by the federal government for Dependent Indian Communities..

${ }_{121} 435$ U.S. 191 (1978).

12225 U.S.C. 1304 et. Seq. The Tribal provisions were part of the Violence Against Woman Act Re-authorization of 2013.

${ }^{123}$ Codified at 25 U.S. C. 1301(2).

${ }^{124}$ See discussion supra at notes...

${ }^{125}$ For an insightful and comprehensive examination of VAWA 2013, see Angela R. Riley, Crime and Governance in Indian Country, 63 UCLA L. Rev. 1565 (2016). 
a. The pool of jurors in such criminal trials has to come from a cross section of the local population with no group, such as non-tribal members, automatically excluded. $^{126}$

b. Tribal governments have to provide an indigent defendant a defense attorney. ${ }^{127}$

c. Defendants have to be given any other rights necessary for the Bill to be constitutional. $^{128}$

d. Defendants have to be provided all other rights available under the Indian Civil Right Act of 1968 as amended, ${ }^{129}$ which include among others the right to effective assistance of counsel if sentences can exceed one year in jail

e. Defendants have the right to appeal their convictions to federal courts pursuant to the writ of Habeas Corpus. ${ }^{130}$

A Bill extending constitutional provisions to non-member civil litigants in tribal courts would be much less burdensome on tribal governments in that constitutional requirements governing civil litigation are less extensive than those applicable to criminal prosecutions. Nevertheless, although advocated by some scholars, ${ }^{131}$ making the Constitution applicable to Indian tribes is politically sensitive and problematic. ${ }^{132}$ The next model would not make constitutional rights per se applicable to Indian tribes.

\section{The Indian Civil Rights Act (ICRA) Model: Providing Non-members Federal Court Review of Alleged ICRA Violations in Civil Cases.}

In 1968, Congress enacted the Indian Civil Rights Act affording the statutory equivalent of almost all the protections of the Bill of Rights to people subjected to tribal governmental power. ${ }^{133}$ However, in Santa Clara Pueblo v. Martinez, ${ }^{134}$ the Supreme Court held that people complaining of civil rights violation could not appeal to federal courts unless they were petitioning the court for habeas corpus. In other words, federal courts did not have jurisdiction over any cases alleging ICRA violations unless the plaintiffs were also incarcerated or their liberty was at least meaningfully restricted.

${ }^{126} 25$ U.S.C. $1304(d)(3)$.

${ }^{127} 25$ U.S.C. (f)(2). Federal grants covering such costs were made available to tribes in the legislation.

${ }^{128} 1304(d)(4)$. Whether any more or all constitutional rights will have to be given has not been answered by the courts yet. See Comment, Special Domestic Violence Criminal Jurisdiction for Indian Tribes: Inherent Sovereignty v. Defendant's Complete Constitutional Rights, 164 U. Pa. L. Rev. 243 (2015).

${ }_{129} 1304$ (d)(2) (Making applicable all rights of defendants under 25 U.S.C. 1302 (c))

${ }^{130} 25$ U.S.C. 1304 (e)(1).

${ }^{131}$ See for instance, L. Scott Gould, Tough Love for Tribes: Rethinking Sovereignty after Atkinson and Hicks, 37 New Eng. L. Rev. 669 (2003).

${ }^{132}$ See discussion at PART III (2).

${ }^{133}$ Pub. Law 90-284, 82 Stat. 73, 25 U.S.C. 1301 et. seq.

${ }^{134} 436$ U.S. 49 (1978). 
One solution, previously recommended by some, ${ }^{135}$ and perhaps less drastic than the previous one, would allow non-members alleging violation of the Indian Civil Rights Act the right to appeal tribal court judgments to federal courts. This proposal is less drastic than the previous one because the ICRA guarantees certain statutory rights that, although similar to some constitutional rights, have not been interpreted as equivalent to constitutional rights. ${ }^{136}$

In Santa Clara Pueblo, the Court first held that the Pueblo could not be sued in federal court because the ICRA lacked clear and unequivocal congressional intent to abrogate tribal sovereign immunity. ${ }^{137}$ Secondly, the Court held that while the official immunity of the tribal officials could implicitly be abrogated, ICRA did not contain such an implied cause of action to that effect. The proposed legislation being discussed here would just create such a cause of action against tribal judges or other tribal officials as long as the non-member complainant alleged that the tribal court proceedings or its implementation resulted or would result in violations of the Indian Civil Rights Act. While this would amount to a modification of Santa Clara Pueblo v. Martinez, it would not totally overrule the case. The proposal would not allow individuals to sue tribes in federal courts for any claimed violation of ICRA. The proposal would only allow non-member defendants to appeal tribal court judgments to federal courts if they are alleging violation of the Indian civil rights Act emanating from tribal court proceedings or orders.

\section{Creating a Presumption of Tribal Jurisdiction Rebuttable When Tribal Courts Have Not Applied Fundamental Notions of Fairness or Due Process}

In an insightful article, Professor Matthew Fletcher argued that the Court should adopt a presumption of tribal jurisdiction over Indian owned lands within Indian reservations. ${ }^{138}$ However, non-members litigants would be able to file lawsuits in federal or state courts in order to rebut the presumption of tribal jurisdiction. The presumption would be rebutted if the non-members were denied a fundamentally fair decision-making process. ${ }^{139}$ His proposal only applies over conduct of non-members on Indian owned land. As to conduct within Indian

135 See for instance, Charles Wilkinson, American Indians, Time, and the Law, at 113-119 (1986). See also Amy Conners, The Scalpel and the Ax: Federal Review of Tribal Decisions in the Interest of Tribal Sovereignty, 44 Colum Hum. Rts. L. Rev. 199, 246-52 (2012).

136 See Developments in the Law: ICRA Reconsidered: New Interpretation of Familiar Rights, 129 Harv. L. Rev. 1709 (2016), Mark D. Rosen, Multiple Authoritative Interpreters of Quasi-Constitutional Federal Law: Of Tribal Courts and the Indian Civil Rights Act, 69 Fordham L. Rev. 479 (2000).

${ }^{137} 436$ U.S. 49 , at 58-59.

${ }^{138}$ Matthew L.M. Fletcher, A Unifying Theory of Tribal Sovereignty, 46 Ariz. St. L. J. 779 (2014).

${ }^{139}$ Id., at 786. 
reservations occurring on land owned in fee by non-members, the Montana analysis would still be applicable. ${ }^{140}$

At first, it seemed that Professor Fletcher's proposal was limited to federal court review for lack of adequate tribal "process" which I understood to mean procedural due process. ${ }^{141}$ However, later parts of his article seem to also advocate for more general federal court review of whether tribal litigants were given enough "American constitutional rights." 142 On the other hand, Professor Fletcher indicated that whether a tribe had provided enough constitutional rights was a determination that could be made along the same lines as what courts do when "deciding whether to grant comity to foreign judgments."143

Professor Fletcher made his proposal while arguing for a shift in the Court's jurisprudence. His argument was not made in connection with proposing legislation. However, when it comes to legislation, a problem with Fletcher's "fundamental fairness" standard is that it would be very complicated to codify. Thus, the statute would have to specify exactly what constituted a denial of "fundamental fairness." Although Professor Fletcher makes a worthy effort to specify what he is envisioning when it comes to fundamental fairness, ${ }^{144}$ the task of actually codifying such concept in legislation could end up being much more complicated and politically difficult than envisioned. Yet without such specifications, the courts would be left to themselves to define such concept and we may end up with just about most of the Bill of Rights applicable to tribal courts. This would make the Fletcher proposal not much different than the two previous ones.

I think one possible reason Fletcher did not confine himself to procedural due process is that his proposal reaches both tribal adjudicative and regulatory jurisdiction and procedural due process rights either do not apply or apply only minimally in the enactment of legislation or regulations. ${ }^{145}$ Because this Essay is only concerned with the civil jurisdiction of tribal courts, Fletcher's proposal should be construed to allow federal court review to rebut the presumption of tribal court civil jurisdiction only in cases where tribal courts have not given nonmembers all the rights required under general notions of procedural due process. ${ }^{146}$

${ }^{140}$ Id., at 830.

${ }^{141}$ See Fletcher, $A$ Unified Theory, discussion at pp. 831-838, mentioning the need for fair, unbiased, and competent tribal judges as well as an independent tribal judiciary.

${ }^{142}$ Id., discussion at pp. 835-838.

${ }^{143}$ Id., at 838 .

14446 Ariz. L. J. at 830-840.

145 This is the classic dichotomy between Londoner v. Denver(adjudication), 210 U.S. 373 (1908), and Bi-Metallic v. Colorado (Rulemaking), 239 U.S. 441 (1915), familiar to all students of Administrative law holding that procedural due process applies to adjudicative proceedings but not to rulemaking.

${ }^{146}$ For another proposal advocating expanded federal court review see Miller, The Shrinking Sovereign: Tribal Adjudicatory Jurisdiction over Nonmembers in Civil Cases, 114 Colum. L. Rev. 1825 (2014). 
In other words, the proposal should not cover all potential denial of constitutional rights to non-members.

Even then, the legislation could be hard to draft with specificity as the panoply of procedural rights is quite large. ${ }^{147}$ Federal courts, however, have developed a comprehensive jurisprudence to determine when and how much process should be given in any given case. ${ }^{148}$ The legislation should therefore give federal courts deference in reviewing tribal proceedings to decide if they have conformed with the requirements of procedural due process. The next section of this Essay addresses a different issue with the three proposals analyzed above: The problem with "constitutionally" incorporating Indian tribes into the federalist system.

\section{A Critique of These Three Proposals: Indian Tribes Should not be Incorporated Within Our Constitutional Federalism.}

In an upcoming article, Professor Michael Doran argued that the Court's implicit divestiture doctrine was a solution the Court devised to protect the constitutional or fundamental rights of non-tribal members without completely destroying tribal sovereignty. ${ }^{149}$ To counter the negative impacts of the implicit divestiture doctrine on tribal sovereignty, Professor Doran summarized various possibilities that would restore tribal jurisdiction but would also protect fundamental rights. However, he ended up finding such proposals either politically unacceptable or otherwise detrimental to Indian tribes. ${ }^{150}$ One of the possible solution he mentioned was allowing Indian tribes to assume full civil jurisdiction over their territories but "forcing tribal governments into the federalist structure." ${ }^{\prime 151}$ This would "require tribal governments to respect fundamental rights of non-tribal members as those rights have been interpreted by the Supreme Court." 152 Describing such solution as a "Devil's Bargain," 153 Professor Doran noted that this remedy may be more harmful to tribes than the implicit divestiture doctrine itself. Underscoring this finding is that Indian tribes are better off remaining "outside" the U.S. constitutional system. In other words, incorporating the tribes within our constitutional system would destroy them as distinct sovereigns and would end up being worse for the tribes even if this meant that under the continued use of the Implicit Divestiture doctrine, tribes would eventually end up losing all civil jurisdiction over non-tribal members.

147 See Goldberg v. Kelly, 397 U.S. 254 (1970)(listing a number of available procedural rights.)

${ }^{148}$ See Matthews v. Eldridge, 424 U.S. 319 (1976).

149 Michael Doran, Redefining Sovereignty for the Era of Fundamental Rights (forthcoming, Indiana Law Review), Electronic Copy available at: https://ssrn.com/abstract=3398215.
${ }^{150}$ Id., at $71-77$
${ }^{151}$ Id., at p. 74.
${ }^{152} \mathrm{Id}$.
${ }^{153}$ Id., at 77 
I have in the past warned against such assimilative influences. ${ }^{154}$ More recently, however, although conceding that making some aspects of due process applicable to Indian tribes would be problematic, ${ }^{155}$ I argued that it may be worth it, especially if that choice was at tribal option. ${ }^{156}$ In her analysis about the implementation of VAWA 2013, Professor Angela Riley also acknowledged the problems with making constitutional provisions applicable to Indian tribes. ${ }^{157}$ However, she concluded that some constitutional provisions could be applied to Indian tribes without jeopardizing their cultural and political distinctiveness. First, she noted that a lot of existing tribal court procedures are already similar if not identical to the ones applied in federal and state courts. ${ }^{158}$ Secondly, she argued that tribes could emphasize their distinctiveness by moving away from the carceral state approach prevalent in federal and state sentencing systems and adopt sentencing provisions more closely affiliated with tribal traditions and culture. ${ }^{159}$

In debating whether tribes already have or should be "incorporated" into the United States, one should keep in mind that there is a difference between "political" incorporation and "constitutional" incorporation, especially if that term is understood to mean that all constitutional provisions would be applicable to tribal governments. I have elsewhere argued that Tribes could be "incorporated" into the United States federalist system without being totally assimilated into the federal structure. ${ }^{160}$ In other words, tribes could be incorporated into the federal system under a third sphere of sovereignty that would allow them to keep their distinctiveness. ${ }^{161}$ Indian tribes have already been, at least partially, politically incorporated into the United States. True enough, there is not one defining congressional Act incorporating tribes into the United States. ${ }^{162}$ However, tribes were geographically incorporated within the territory of the United States under the doctrine of Discovery as interpreted in Johnson v. M'Intosh. ${ }^{163}$ Furthermore, they were politically incorporated incrementally within the United States system as

${ }^{154}$ See Alex Tallchief Skibine, Troublesome Aspects of Western Influence on Tribal Justice System and Laws, 1 Tribal Law Journal 2007

155 See Skibine, Inherent Powers of Indian Tribes, supra note 12, at 132-133, citing Christine Zuni, Strengthening What Remains, 7 Kans. J. L. \& Pub. Pol'y 17 (1997).

${ }^{156}$ Id., at 134.

157 Angela Riley, Crime and Governance in Indian Country, 63 U.C.L.A. L. Rev 1565, 1595-1603 (2016).

${ }^{158}$ Id., at 1614. See also Barbara L. Creel, The Right to Counsel for Indians Accused of Crimes: A Tribal and Congressional Imperative, 18 Mich. J. Race \& L. 317, 320-321 (2013).

${ }^{159}$ Id., at 1622-1630.

160 See Alex Tallchief Skibine, Constitutionalism, Federal Common Law, and the Inherent Powers of Indian tribes, 39 Am. Ind. L. Rev. 77 (2014-15).

${ }^{161}$ Id., at 689-693 (arguing for a self-determination Paradigm of incorporation.)

162 See Milner S. Ball, Constitution., Court, and Indian Tribes, 1987 Am. B. Found. Res. J. 1, 37 (1987).

${ }^{163} 21$ U.S. 543 (1923). 
a result of cumulative legislation enacted by Congress throughout history: ${ }^{164}$ Legislation such as the Indian Citizenship Act of $1924,{ }^{165}$ the Indian Reorganization Act of $1934,{ }^{166}$ the Indian Civil Rights Act of $1968,{ }^{167}$ and the Indian Self Determination Act of 1975 . $^{168}$

It is true, however, that the tribes have never been constitutionally incorporated into the United States. ${ }^{169}$ As Professor Frank Pommersheim has urged, the confusion surrounding the constitutional status and incorporation of Indian tribes within our federalist system should be resolved through a constitutional amendment. ${ }^{170}$ In the last Part of this Article, I attempt to counter the effect of the implicit divestiture doctrine without assimilating the tribes constitutionally into the federal structure.

\section{PART III: INCORPORATION WITHOUT ASSIMILATION: MINIMIZING FEDERAL COURTS INTERFERENCE WITH TRIBAL LEGAL NORMS}

\section{Making Personal Jurisdiction Doctrines Applicable to Tribal Courts}

In this part, following on an idea expressed by Professor Katherine Florey, I propose to legislatively reconfirm tribal court jurisdiction over all causes of actions arising in Indian Country as long as the tribal court can establish personal jurisdiction over the parties. ${ }^{171}$

In her Article, Professor Florey convincingly demonstrated that the Supreme Court's statement first enunciated in Strate v. A-1 Contractors, ${ }^{172}$ that "A tribe adjudicative Jurisdiction does not exceed its legislative jurisdiction," 173 has no theoretical validity. ${ }^{174}$ Other commentators have also noted that the Court never

164 See generally, Alex Tallchief Skibine, Redefining the Status of Indian Tribes within "Our Federalism": Beyond the Dependency Paradigm, 38 Conn. L. Rev. 667, at 669-677 (2006).

1658 U.S.C. $1401(\mathrm{~b})$.

16625 U.S.C. 461 et seq.

16725 U.S.C. 1301 et. seq.

16825 U.S.C. $450 \mathrm{a}-450$ n.

169 See David E. Wilkins, A Constitutional Confession: The Permanent Malleable Status of Indigenous Nations, 37 New Eng. L. Rev. 473 (2003).

${ }^{170}$ Frank Pommersheim, Is there a (Little or not so Little) Constitutional Crisis Developing in Indian Law?: A Brief Essay, 5 U. Pa. J. Const. L. 271, 285 (2003).

171 See Katherine Florey, Beyond Uniqueness: Reimagining Tribal Courts' jurisdiction, 101 Cal L. Rev. 1499 (2013). Other scholars have expressed similar views. See for instance Sarah Krakoff, The Renaissance of Tribal Sovereignty: The Negative Doctrinal Feedback Loop and the Rise of the New Exceptionalism, 119 Harv. L. Rev. F. 47, $52-53$ (2005)

172520 U.S. 438 (1997)

${ }^{173}$ Id., at 453. See also Nevada v. Hicks. 533 U.S. 353, at 367 (2001)(endorsing the statement).

${ }^{174}$ Florey, Beyond Uniqueness, at 1532-1536. 
gave any reasons whatsoever for this statement. ${ }^{175}$ Florey's argument is that tribal courts should be considered courts of general jurisdiction and be treated like state courts when it comes to determining the extent of their jurisdiction.

Professor Florey further explained that the Court's concerns with lack of due process in tribal court proceedings would be taken care of by having the doctrines of personal jurisdiction applicable to tribal courts in the same fashion as they are applied in state and federal courts. ${ }^{176}$ According to Florey, the Court in International Shoe v. Washington, ${ }^{177}$ devised a test allowing a court's jurisdiction as long as the defendant maintained minimum contacts with the jurisdictional forum and such judicial jurisdiction did not offend traditional notions of fair play and substantial Justice. ${ }^{178}$ Furthermore, Professor Florey noted that in Asahi Metal Industry v. Superior Court, ${ }^{179}$ the Court took the position that "even if minimum contacts were present, a lack of reasonableness could defeat personal jurisdiction." 180 As Florey explained, "reasonable concerns about fairness, bias and unfair surprise exist when non-members $\ldots$ are haled into tribal courts as defendants," however, these "are the traditional concerns of personal jurisdiction." $" 181$

Tribal courts have in the past already used principles of personal jurisdiction derived from U.S. Supreme Court precedents to determine their own jurisdiction. ${ }^{182}$ It is important to note, however, that principles of constitutional due process applied to delineate the extent of personal jurisdiction by the United States Supreme Court are currently not applicable to tribes as such since tribes, unlike the states and the federal government, are not bound by the United States Constitution. ${ }^{183}$ As one commentator has argued, however, due process requirements are already applicable to tribes through the Indian Civil Rights Act (ICRA). ${ }^{184}$ That same commentator also argued, however, that federal courts have

${ }^{175}$ See for instance M. Gatsby Miller, The Shrinking Sovereign: Tribal Adjudicatory Jurisdiction over Nonmembers in Civil Cases, 114 Colum. L. Rev. 1825, 1837 (2014) (noting the lack of justifications and attempting to provide some.

${ }^{176}$ Florey, Beyond Uniqueness, at 1506-07.

177326 U.S. 310,316 (1945) (emphasis added).

${ }^{178}$ Florey, Beyond Uniqueness, at 1510.

179480 U.S. 102 (1987).

${ }^{180}$ Florey, at 1556.

${ }^{181}$ Florey, Beyond Uniqueness, at 1557.

${ }^{182}$ See Grant Christensen, Personal Jurisdiction and Tribal Courts After Walden and Bauman: The inadvertent impact of Supreme Court Jurisdictional Decisions on Indian Country, 68 Rutgers U. L. Rev. 1367, 1378 (2016)(stating that although tribal courts do not have to abide by the same constitutional standards as state and federal courts, "In practice, however, tribal courts consult Supreme Court precedent such that the meaning of due process found in the Indian Civil Rights Act is given a virtually identical meaning to the clause in its Fourteenth Amendment sister." Id.

${ }^{183}$ Talton v. Mayes, 163 U.S. 376 (1896).

184 See David A. Castleman, Personal Jurisdiction in Tribal Courts, 154 U. Or. L. Rev. 1253 (2006). 
not and should not find an implied cause of action in the ICRA for challenging tribal courts determinations of personal jurisdiction to federal courts. ${ }^{185}$

Under my proposal, which would impose constitutionally based requirements of personal jurisdiction on tribal courts, findings of personal jurisdiction by tribal courts would be appealable to federal courts after exhaustion of tribal court remedies. Such exhaustion requirements are currently mandated under National Farmers Union v. Crow Tribe ${ }^{186}$ Although the general rule mandating exhaustion of tribal court remedies was imposed before plaintiffs could challenge the subject matter jurisdiction of tribal courts, they should remain applicable to a challenge of personal jurisdiction determinations made by tribal courts as the normative reasons for the general rule would still be applicable. ${ }^{187}$ Initially, the Court did note three exceptions to the tribal exhaustion doctrine. ${ }^{188}$ These three exceptions would continue to be applicable to cases challenging the personal jurisdiction determinations made by tribal courts under my proposal. In Strate v. A-1Contractors, however, the Court added a fourth exception, stating "When, as in this case, it is plain that no federal grant provides for tribal governance of nonmembers' conduct on land covered by Montana 's main rule, it will be equally evident that tribal courts lack adjudicatory authority over disputes arising from such conduct."189 That exception would no longer be applicable under my proposed legislation since the legislation would reaffirm the subject matter jurisdiction of tribal courts as long as the constitutional due process requirements for personal jurisdiction were met.

185 Id., at 1277-1281. The commentator noted under current Supreme Court jurisprudence, it is even harder to find a implied statutory cause of action than it was in 1978 when the Court in Santa Clara Pueblo v. Martinez, 436 U.S. 49, refused to find an implied cause of action against tribal officials for alleged violations of the Indian Civil Rights Act. Id., at 60-66.

186471 U.S. 845 (1985).

187 As the National Farmers Court stated: "We believe that examination should be conducted in the first instance in the Tribal Court itself. Our cases have often recognized that Congress is committed to a policy of supporting tribal self-government and selfdetermination. That policy favors a rule that will provide the forum whose jurisdiction is being challenged the first opportunity to evaluate the factual and legal bases for the challenge. Moreover, the orderly administration of justice in the federal court will be served by allowing a full record to be developed in the Tribal Court before either the merits or any question concerning appropriate relief is addressed... Exhaustion of tribal court remedies, moreover, will encourage tribal courts to explain to the parties the precise basis for accepting jurisdiction, and will also provide other courts with the benefit of their expertise in such matters in the event of further judicial review, 471 U.S. 845, 856-57 (1985).

188 The National Farmers Court stated "We do not suggest that exhaustion would be required where an assertion of tribal jurisdiction "is motivated by a desire to harass or is conducted in bad faith, or where the action is patently violative of express jurisdictional prohibitions, or where exhaustion would be futile because of the lack of an adequate opportunity to challenge the court's jurisdiction.” Id., at 857.

${ }^{189} 520$ U.S. 438,459 (1997). 
At this point, some may argue that there is not that much difference between my proposal and Professor Fletcher's. Set forth below is an enumeration of the differences:

First, probably to make his proposal more palatable to anti-tribal interests, Professor Fletcher restricted his proposal to Indian owned fee land within the reservation and stated that tribal jurisdiction over non-member owned land should continue to be determined under the Montana doctrine. Under my proposal, the legislative restoration of tribal jurisdiction over non-members would include all lands within tribal territories. Secondly, I am confining my legislative restoration to the adjudicative jurisdiction of tribal courts. Unlike Fletcher, I do not address the legislative/regulatory jurisdiction of tribal governments. Under my proposal, tribal regulatory jurisdiction over non-members would continue to be determined under Federal common law. Third, federal court review of tribal court jurisdiction under my understanding of Professor's Fletcher proposal is confined to looking for lack of procedural due process. Under my proposal, federal courts would just review whether tribal courts correctly determined that they had personal jurisdiction over the parties.

I understand that, politically speaking, transposing the Florey personal jurisdiction approach to a legislative proposal may be seen as too pro tribal for those in Congress who are objecting to tribal jurisdiction. The rest of this Essay will explore this issue.

\section{General Difficulties with Enacting Pro-tribal Legislation}

Past legislative settlements in the field of Federal Indian Law have required many compromises with non-tribal interests. So far, the pro tribal interests managed only a partial overturning of Oliphant 35 years after the Court issued that decision. ${ }^{190}$ On top of that, the tribes still had to guarantee the required constitutional protections before being allowed to reacquire such jurisdiction. ${ }^{191}$ In other areas of federal Indian law, while Congress was able to initially enact a relatively balanced compromise on Indian gaming with the passage of the Indian Gaming Regulatory Act (IGRA) of $1988,{ }^{192}$ tribal interests have not yet been successful in overcoming the negative impacts of the Court's decision in Seminole Tribe v. Florida, ${ }^{193}$ where the Court held that Congress could not use its Indian Commerce power to abrogate the states' Eleventh Amendment sovereign

${ }^{190}$ See discussion supra at notes...

${ }^{191}$ See discussion at notes...

${ }^{192}$ Pub. L. 199-497, 102 State 2467 (1988)(codified at 25 U.S.C. 2701 et.seq.). For a comprehensive description of the negotiations that led to IGRA by one of the key players in such negotiations, see Franklin Ducheneaux, The Indian Gaming Regulatory Act: background and legislative History, 42 Ariz. St. L. J. 99 (2010).

${ }^{193} 517$ U.S. 44 (1996). 
Immunity so as to allow tribes to sue states that failed to negotiate in good faith the required tribal state gaming compacts. ${ }^{194}$

Similarly, the tribes have yet to successfully push a legislative fix to the controversial Carcieri decision, ${ }^{195}$ which held that only tribes under federal jurisdiction as of 1934 could benefit from a section in the law allowing the Secretary of the Interior to transfer land into trust for the benefit of Indian tribes. ${ }^{196}$ The same goes for Alaska v. Village of Venetie, ${ }^{197}$ another questionable opinion where the Court declared that the 40 million acres set aside for Alaskan Indians in the Alaskan Native Claims Settlement Act (ANCSA) were not Indian Country. ${ }^{198}$ This meant that federally recognized Indian tribes in Alaska could no longer exercise regulatory jurisdiction over the lands they owned in fee pursuant to ANCSA.

The lack of success in the areas just mentioned does not mean that Indian tribes are never successful. ${ }^{199}$ There has been dozens of tribal land settlement Acts enacted into law, ${ }^{200}$ and an even larger amount of Indian Water Rights Settlements. ${ }^{201}$ In addition, there are dozens of tribal specific bills enacted in every Congress, one of them even overturned an anti-tribal Supreme Court decision. ${ }^{202}$ However, the tribes will need to put forward some compelling reasons as to why legislation restoring tribal courts' civil jurisdiction over non-members is important and necessary. Professors Fletcher and Tweedy have each enumerated some valid reasons supporting at least some restoration of tribal civil jurisdiction. ${ }^{203}$ Thus, Fletcher cited 1. Congressional and Executive public policy, 2. Protecting the dignity of tribes as sovereigns, 3. Improving tribal governance capacity, 4. Evolving tribal economic and political circumstances, and 5. Lack of federal and state court jurisdiction over tribal lands. ${ }^{204}$ Tweedy added 1. Erosion of tribal

${ }^{194}$ Pub. L. 100-497, 102 Stat. 2467 (1988), codified at 25 U.S.C. 2701 et seq. On this topic, see Matthew L.M. Fletcher, Bringing Balance to Indian Gaming, 44 Harv. J. on Leg. 39 (2007).

195 Carcieri v. Salazar, 555 U.S. 379 (2009)

${ }^{196}$ For a comprehensive analysis of the decision and this area of the law, see William Wood, Indian Tribes, and (federal) Jurisdiction 65 U. Kansas L. Rev. 415 (2016).

197522 U.S. 520 (1998)

${ }^{198} 43$ U.S.C. 1601 et seq. See generally, Gregory D. Strommer and Stephen D. Osborne, Indian Country and the Scope of Tribal Self-Government in Alaska, 22 Alaska L. Rev. 1 (2005).

${ }^{199}$ See Carlson, Congress and Indians, supra at note 16.

${ }^{200} \mathrm{Id}$.

201 At last count, there were some 32 Indian water rights settlements that had been enacted into law since 1978. For a summary and analysis of some of these water rights settlement, see Robert T. Anderson, Indian Water Rights, Practical Reasoning, and Negotiated Settlements, 80 Cal. L. Rev. 1133 (2010).

202 See Pub. L. No. 113-179, 128 Stat. 1913 (overturning Match-E-Be-Nash-She-Wish Band of Pottawatomi Indians v. Patchak, 567 U.S. 209 (2012).

${ }^{203}$ See Fletcher, A Unifying Theory, supra at note..., Tweedy, Connecting the Dots, supra at note......

${ }^{204}$ Fletcher Id. At 804-821. 
culture and institutions, 2. Disempowerment of tribal courts, 3. Lack of respect for tribes, 4. Lack of funding for tribal justice systems, 5. Waste of resources, 6. Inability to protect tribal interests, and 7. Lawlessness. ${ }^{205}$

Yet, I understand that allowing tribal jurisdiction over non-members as long as personal jurisdiction can be established could face an uphill battle even if tribal courts' findings of personal jurisdiction can be appealed to federal courts. For one thing, it will be increasingly hard for tribes to push legislation restoring some kind of tribal civil jurisdiction over non-members if lobbying groups opposed to tribal jurisdiction start believing that the Court will eventually prohibit all tribal civil jurisdiction over non-members. To counter this problem, in the next section, I propose a political compromise that some tribes may wish to consider in order to convince groups generally opposed to tribal jurisdiction not to lobby against the proposal.

\section{Facilitating Passage of the Legislation by Allowing for Removal of Tribal Court Cases to Federal Courts}

One possible idea to improve the chances of passing the proposed legislative solution would be to allow non-member defendants being sued in tribal courts to remove their cases to federal courts under certain circumstances. This proposal would follow the model set forth in 28 U.S.C.1441 for removal of civil actions from state to federal courts. ${ }^{206}$ In other words, removal could be granted only in cases the federal court would otherwise have jurisdiction. In other words, in cases involving federal questions or meeting the diversity requirements.

I am aware that this removal option may not be popular with some tribal advocates. Yet, I believe this proposal may be less drastic or detrimental to tribal sovereign interests than anticipated: First, the burden to persuade federal courts to accept removal would be on the non-tribal parties seeking removal. These removal requirements can be hard to navigate. ${ }^{207}$ Secondly, even if a case is removed, the law of the initial forum, tribal law, should still be applicable to the proceedings. ${ }^{208}$ Finally, in order to limit federal interference with the distinct nature of tribal judiciaries, ${ }^{209}$ I would not grant an unlimited right to remove tribal cases to federal

205 Tweedy, id., at pp. 683-689.

20628 U.S.C 1441 (a) reads: Except as otherwise expressly provided by Act of Congress, any civil action brought in a State court of which the district courts of the United States have original jurisdiction, may be removed by the defendant or the defendants, to the district court of the United States for the district and division embracing the place where such action is pending."

${ }^{207}$ Foe a concise summary see, Charles J. Hyland, Removal for Federal Court: The Practitioner's Tightrope, 63-Nov J. Kan. B.A. 22 (1994).

208 See Katherine J. Florey, Choosing Tribal Law: Why State Choice-of-Law Principles Should Apply to Disputes with Tribal Contacts, 55 Am. U. L. Rev. 1627, 16511655 (2006)(explaining modern choice of law theories.)

${ }^{209}$ For an argument supporting the benefits of having tribes remain as culturally and politically different from non-tribal governments see Gloria Valencia Weber, Tribal 
courts. Instead, federal courts should abstain from granting removal in cases where important tribal governmental interests are involved unless the federal court finds that the litigation below was 1 . motivated by a desire to harass, or 2 . conducted in bad faith, or 3. tribal jurisdiction was plainly lacking, or 4. the non-member defendant lacked a fair opportunity to present his case in that the tribal forum was biased or the non-member party was barred on procedural grounds from raising his claims.

This modification/addition to the removal requirements contained 28 USC 1441 somewhat tracks the exceptions to the exhaustion of tribal remedies doctrine,${ }^{210}$ but recast them in a different context. It is also inspired by the Younger Doctrine, ${ }^{211}$ as well as the other federal abstention doctrines. ${ }^{212}$ The three requirements for Younger to apply are: 1. Parallel state proceedings, 2. Implication of important state interests, and 3. Lack of adequate forums for the party resisting abstention to raise her (federal) claims. ${ }^{213}$ On the other hand, the three exceptions to application of Younger abstention are: 1. Bad faith and harassment, or 2. A patently unconstitutional state statute, or 3. An inadequate state forum in that it is biased or the party is barred on procedural grounds from raising its federal claims. $^{214}$

An option worth considering from a tribal perspective would be to limit removal to federal question cases and not include diversity. Similarly, those opposed to tribal jurisdiction would probably push to go beyond diversity of state citizenship and allow all non-members to remove cases to federal courts. The normative argument against both these positions, one pro tribal the other one not, is that in order to be correctly integrated into the federal system, tribal courts should be treated, as much as possible, on par with state courts when it comes to their relations with the federal courts. Thus, for uniformity sake, the whole federal

Courts: Custom and Innovative Law, 24 N.M. L. Rev. 225 (1994), Katherine Florey, Making it work: Tribal Innovation, State Reaction, and the Future of Tribes as Regulatory Laboratories, 92 Washington L. Rev. 713 (2017).

${ }^{210}$ See discussion supra at note ...

${ }^{211}$ Younger v. Harris, 401 U.S. 37 (1971).

212 Generally speaking, the federal abstention doctrines are based on notions of federalism aimed at protecting the sovereign interests of the states of the Union. Therefore, these doctrines would not be applicable to shield Indian tribes from federal interference. For a short overview of the abstention doctrines, see Beth Shankle Anderson, "Our Federalism," the Younger Abstention Doctrine, and its Companions, 81-Nov Fla. B. J. 9 (2007).

213 On the Younger Abstention doctrine and its intricacies in the context of removal see Plitt and Rogers, CHARTING A COURSE FOR FEDERAL REMOVAL THROUGH THE ABSTENTION DOCTRINE: A TITANIC EXPERIENCE IN THE SARGASSO SEA OF JURISDICTIONAL MANIPULATION, 56 DePaul L. Rev. 107. See also, Daniel C. Norris, The Final Frontier of Younger Abstention: The Judiciary's Abdication of the Federal Court Removal Jurisdiction Statute, 31 Fla. St. U. L. Rev. 103 (2003).

${ }^{214}$ See Drew Alan Hillier, Note, The Necessity of an Equity and Comity Analysis in Younger Abstention Doctrine, 46 Conn. L. Rev. 1975 (2014) (explaining the Younger exceptions). 
removal statute should, to the extent possible, treat tribal and state courts in the same fashion.

\section{CONCLUSION}

For about forty years now, the Supreme Court has been engaged in a measured attack on tribal sovereignty when it comes to tribal jurisdiction over nonmembers. Although the Court has devised a test seeming to determine the amount of tribal jurisdiction on whether the exercise of that governmental power is "necessary" to tribal self-government, in reality, the Court wants to protect or shield non-members from tribunals that are not bound by the Constitution's Bill of Rights. ${ }^{215}$ Also of concern to the Court is the fact that tribal court orders in the area of civil jurisdiction are not appealable to federal courts except when one is challenging the subject matter jurisdiction of the tribal court. ${ }^{216}$ To remedy this situation, this Essay has proposed a legislative solution which would reaffirm the civil jurisdiction of tribal courts over non-member defendants as long as personal jurisdiction over such parties could be established. However, tribal court determinations of personal jurisdiction could be appealed to federal forums. Furthermore, in order to facilitate enactment of such legislation, this Essay has suggested that tribes should consider adding legislative language allowing nonmembers being sued in tribal forums to remove their cases to federal courts if certain conditions are met.

I believe this solution goes a long way in incorporating or reconfirming Indian nations as the Third Sovereign within the United States' legal system. ${ }^{217}$ At the same time, it achieves this goal without "assimilating" Indian Nations within our constitutional system in that it does not make the tribal courts subject to all constitutional restrictions except for the requirements of establishing personal jurisdiction.

${ }^{215}$ See Doran, Redefining Tribal Sovereignty for the Era of Fundamental Rights, supra at note...

${ }^{216}$ See discussion at note ...

${ }^{217}$ See Sandra Day O'Connor, Lessons from the Third Sovereign: Indian Tribal Courts, 33 Tulsa L.J. 1 (1997). 